Scottigh Tradition $\mathfrak{Y 0 l . 2 2 1 9 9 7}$

\title{
Traditional Gaelic \\ Piping and Class in 19th Century Nova Scotia
}

hroughout the times of the great Highland emigrations to the New World, very much more of Gaelic musical tradition than has been imagined owed its vigour and persistence to the patronage and attitudes of the Gaelic middle-class. The persistence of the idea of the force of patronage of the musically talented, just as with the bardically gifted, is to be found in the New World Gàidhealtachd, as in the Old, but the barriers to understanding that force in its modified New World form, and at this distance from the immigrant generations, are not inconsiderable.

Even in the Old World, in the late 18th century, the bonds that united the Gaelic classes permitted public familiarities that outsiders often found remarkable and unbecoming. ${ }^{1}$ In the New World the new land tenure system blurred, for a non-Gael, residual social distinctions that were obvious to the traditional Gael.

In Scotland, before the enforcement of the Tenures Abolition Act $^{2}$ (which banned the holding of land in return for military service), and the Heritable Jurisdictions Act, in 1746,3 many chiefs, although already culturally distanced from the ordinary Gael, took 


\section{Scottish Tradition $\mathfrak{Y o l . 2 2} 1997$}

advantage of the old system which promoted inter-class ties. When chiefs fell out of Gaelicness completely, ${ }^{4}$ the still Gaelic-speaking middle class often continued it. These are an important force for the persistence of tradition in the Old and New Worlds.

The themes of Gaelic community life were, as they remain, relatedness and social cohesion, and, until differing times from the 1760s until late into the the 19th century in Scotland, what persisted of the Gaelic middleclass promoted this by control of land and water use. By control of any agricultural surplus and the forgiving of rents in climatic and economic hard times, the loyalty of the sub-tenant farmer and his inferiors was guaranteed.

Until long after 1746 , while the socio-political and economic system was thus de facto independently Gaelic, much of the middle-class was of necessity Gaelic-speaking, and while the middle-class was at least bi-lingual, Gaelic/English, shared social amusement was perceived by all as eminently worthy of attention, of fostering and promotion. Traditional music was shared by middle class and ordinary Gael alike and was an essential bond in Highland society.

As long as unilingual Gaelicness endured, ${ }^{5}$ social concepts were Gaelic social concepts and the class system persisted. In places like Raasay, Gairloch and Glenaladale, until long after the Napoleonic Wars there were relatively complete Gaelic sociocultural systems operating within the loose embrace of the outsider's political and legal imposure.

Music and dance were integral in that world and it 


\section{Scottigh Tradition $\mathcal{Y o l . 2 2 ~} 1997$}

was a world that revealed much of its cultural richness to Iain Og Ile in the 1860s. Alexander Smith described the abrasion of the traditional and the modern worlds in Skye in or before $1866 .{ }^{6}$ Traditional bagpiping and dancing were still alive and kicking in South Uist at the turn of this century. ${ }^{7}$ Unfortunately little interest was paid to dance-music piping and so much to converting tradition to the improver models.

Just what sorts of advantages community pipers had from the setters of the land by the 1850 s has been no academic's focus. In some cases there were none. In the 1790 s, Invernesshire decreets of removals, for example, mention bagpipers. ${ }^{8}$ In other cases pipers were selectively better treated.

What is generally known of the patronage of pipers in Scotland, from writers in English such as James Logan (1831), and later writers, is superficial. It only deals with the chiefly level of Gaelic society. The musician belongs to a select group of pipers devoted to the playing and composition of Gaelic court music, transmitted without written music. This level of Gaelic piper is present in Nova Scotia in the late 18th and early 19th centuries but here he was pathetically adrift from his sponsor and the artificiality of the Highland equivalent of court circumstances.

Nonetheless these pipers saw themselves as members of the Gaelic middle-class, and, in the case of Lt Donald MacCrumen at East side Jordan Bay ${ }^{9}$ and John MacKay in forest New Glasgow ${ }^{10}$ this was justifiable to some extent. MacCrimmmon went home from Nova Scotia in 


\section{Scottish Tradition YOol.22 1997}

1790. John Mackay stayed but is forgotten as a piper.

The crux of the matter is that, in Nova Scotia, any idea of patronage which operated, concerned the community musician, the sort of person who in Scotland had owed, in some degree as yet not adequately defined, his farm and his subsistence, or later a steady job, to his social function as one of the community's musicians. At the time of the clearances in the early 19 th century, for example, some pipers, like John Campbell, a dance-music piper in the Great Glen, ${ }^{11}$ were given an option by virtue of their social significance to Gaelic society. 12 A large number however emigrated.

This class of piper was common throughout the Scottish Gàidhealtachd and his significance in the Gaelic scheme of life there, and in Nova Scotia, is much more important than has been recognised. Scottish writers on piping, in general, could not be bothered to find him, and when they did, often ignored him, denigrated him or just noted his presence without trying to understand his music and why it was important.

Nonetheless, Scottish literature does lead one to conclude that the fiddler and the ordinary piper flourished in Gaelic Scotland all right, but independent of any encouragement and sponsorship by the middle and upper class. This attitude has been encouraged by the tourist writings of people like Penant, Necker de Saussure, MacCulloch and a host of others all of whom were influenced by the Highland Societies' attitudes to piping which centred on the exclusive promotion, by competition, of classical bagpiping only. 


\section{Scottigh Tradition $\mathcal{Y o l . 2 2 ~} 1997$}

The same artificial, repertoire-exclusive attitude, the one of disdain which tells its votary that it was infra dignitatem to consider oneself of any musical significance in Gaelic Scotland if one did not play the Gaelic bagpipe's court music, has carried into the present century and is implicit in the attitudes of countless people interested in piping, but not in traditional Gaelic piping. This notion, demonstrably incorrect as it is, has deeply influenced and limited Scottish thought on piping, bringing to it an alien snobbery that is out of place in that segment of Gaelic society.

On the other hand, Rev. Norman MacLeod, (Caraid nan Gàidheal) in the 1830 s inadvertently painted a good picture, in Gaelic, of the community piper, Fionnladn Piobair', in Glendessary. ${ }^{13}$ Uncounted pipers like Fionnladh Piobair' came to Nova Scotia and elsewhere in the New World. The MacDougall piper in the Margarees from the late 1820 s is probably typical of all Gaelic

communities here and elsewhere; he is only known to us from MacDougall's History of Inverness County. He, however, is remembered in print in Nova Scotia while Donald MacCrimmon and John MacKay are not.

Nova Scotia's importance to the story of traditional bagpiping is all the more emphasized because, in Scotland, modernising forces, which radically changed piping, were at work from about the middle of the 19th century. Regal interest in Highland affairs hastened outside non-comprehending, but influential, interest in Gaelic musical culture at exactly the time when the 


\section{Scottish Tradition $\mathfrak{Y o l . 2 2} 1997$}

massive emigrations had rendered the old culture most introverted and vulnerable. ${ }^{14}$ Nova Scotia, and surely also elsewhere in the New World, missed all of this and the old Gaelic community piper survived long into the 20th century. The last exponent of the preliterate art in Cape Breton, Alex Currie (b. 1910), is still alive, and sought as a traditional teacher. Currie's piping satisfied community step-dance requirement but nothing is known of middle-class encouragement of him or his piping forebears.

Nonetheless to come to grips with encouragement of all social levels of pipers and to see Nova Scotia, and its importance, in a sharper perspective, one has to rectify the repertoire-exclusive attitude. In 18th century Scottish Gaelic poetry, piping and fiddling for dancing are time and again mentioned with great pride, often given as praise-worthy talents shared among the classes. Joseph MacDonald, in 1761, made no status distinction between court and dance-music piping..$^{15}$ By comparison, Logan's and others' observations are almost always shallow and contrived.

So, from the middle of the 19th century Scotland was in fact not so lucky as rurally isolated Gaelic Nova Scotia. In Scotland new artificialities were created and with the spread of literate learning of piping in the 19th century, ways emerged to ensure continuation of this unGaelic idea. Competition and the idea of improvement stretched tradition thin, finally destroying it through classroom teaching of piping by great literately-trained pipers like John MacDonald and Willie Ross in the Gaelic 


\section{Scottigh Tradition $\mathcal{Y o l . 2 2 ~} 1997$}

heartlands of the Outer Hebrides, especially South Uist. ${ }^{16}$ In fact, in 19th century Scotland, the new standards required spread down to all levels of piping and willy-nilly, eventually destroyed the older spontaneity of Gaelic bagpiping. To see further back, into Gaelicness, you have to look to New World Gaeldom.

The involvement of the old Gaelic-speaking middle class in Nova Scotia in traditional piping, fiddling and dancing has never been thoroughly studied either. The group is not known to have had a distinctive accent and was not easily distinguishable by landownership but it and its cultural significance existed and is important for culture's endurance. ${ }^{17}$

The people who came out have often been considered the poor but the truth of the matter, judging by the alarm of people whose livelihoods depended on a good, regular Sabbath collection, is that it was the poor who were left behind. ${ }^{18}$ And it was not limited to the Roman Catholic community. The Rev. Norman MacLeod and Stewart of Garth both lamented the disappearance of the solid old Gaelic middle class, and the solid old tenant farmer, and any understanding of the lives and prides of the last Gaelic-speaking generations in Nova Scotia must include very prominently the realisation that there was a typical mixture in Nova Scotia of people who considered themselves middle-class in Gaelic terms, as well as the better-off of their tenantry and their dependents. In most of the emigrations large parts of integrated communities came out and settled together, musicians and all, and attracted others later. 


\section{Scottish Tradition YOol.22 1997}

It must be admitted that the importance of the middle-class Gaelic piper like Donald MacCrimmon, John MacKay and others like them ${ }^{19}$ in Nova Scotia is limited to the fact that they are well-known in Scotland. There their "greatness" is still accepted unquestioningly, so that mention of them, almost anywhere, automatically opens the door crack to the more important subject of tradition and the middle-class.

Nova Scotia received many other pipers, like MacDougall from Morar in South West Margaree, Inverness county, Glenaladale's piper in Highfield and the piper Campbells in Pomquet, Antigonish county.

They are remembered mostly by latter-day Nova Scotia Gaels writing in English in the 20th century. 20 Almost every local genealogy of Highlanders settling in Canada gives examples of pipers, although seldom much more than a name is offered. Actually, during the immigrants' years pipers are more often mentioned and named than fiddlers.

In Nova Scotia, in the New World Gàidhealtachd, community pipers were a formidable feature of the socio-musical landscape until the Great War, and they were not uncommon during the Second World War, and lingered on into the civilian pipe-band era. Their prime function was to play step-dance music for the céilidh (and weddings and other events). In this they were simply continuing practices usual in the old World Gàidhealtachd where reliable written records prove middle-class participation in Reel dancing and other rustic musical pastimes. 


\section{Scottigh Tradition $\mathcal{Y o l . 2 2 ~} 1997$}

There can be no doubt that the people in positions of sufficient power in Gaelic Scotland to settle tenantry on the land, had a pronounced interest in having popular traditional dance-music musicians among their tenants. In many instances these were the same people who organised and led the emigrations to the New World. The same mix of social strata occurred in Nova Scotia that had existed in Highland Scotland. The same Highland understanding and acceptance of many elements of social stratification continued to live in the minds of immigrant Gaels, for as long as the primary language was Gaelic.

In the New World however, everyone owned land, or looked forward to that. The deference owed by renter to owner was gone and what was left in colonial Canada was the British deference owed by the uneducated class to the educated and more powerful, a deference ingrained in Gaelic society in any case. Captain John MacDonald (Glenaladale) and Conduiligh Rankin ${ }^{21}$ enjoyed middle-class status and respect in several ways as community leaders in Prince Edward Island although once in the New World their former tenants and followers were unwilling to accept tenant status when land ownership was possible. The same respect for middleclass Gaels existed in Nova Scotia. Justices of the Peace, merchants, religious and political leaders, teachers, occasional militia leaders and "esquires" who were Gaels all form a strong, well-distributed and (with exceptions) respected class in rural Nova Scotia. Ray MacLean's recent book The Casket nicely reveals an occasionally 


\section{Scottish Tradition $\mathfrak{Y o l . 2 2} 1997$}

published middle-class testiness at being socially overlooked by Britain. Official and professional occupations identified the middle class.

Gaelic society's cohesion in Nova Scotia was proverbial. The absence of crime (and any police force) and the widely-accepted restraints on physical violence point to a very strongly respected set of traditional norms which were reinforced by men like Captain Allan MacDonald in the Margarees, the John MacLellan teacher in Mabou Coal Mines, John MacKinnon, MLA and a piper, in William's Point, the Tulloch MacDonalds at West Lake Ainslie and Mabou Coal Mines, the descendants of the Keppoch and Killiechonate MacDonalds (also including one prominent piper), the Retlands and many other descendants of Gaels who had been prominent in the Highlands.

The facet of 19th and early 20th century Nova Scotian Highland history which often is overlooked is that it was resolutely pro-British; and British society, in and before the Victorian era, was a world phenomenon and profoundly class conscious. Gaelic society was linguistically isolated. It was by and large ignored at the empire's epicentre but it was by no means ignorant of British affairs. British military heros like Hector MacDonald were known and admired in the most rural Highland home in Cape Breton long after Confederation in 1867. In the New World, survival's formula contained a large dose of social conservatism. In its musical and dance retentions Gaelic Nova Scotia is uniquely important

to

Gaelic 


\section{Scottigh Tradition $\mathcal{Y o l . 2 2} 1997$}

studies and this reflects a sustaining of tradition by all strata of rural Gaelic society, not just a part.

What happened to that important cultural imprimatur of the middle-class? One segment of Nova Scotian Gaelic society in the 19th century enjoyed, or endured, control that was even more strict than in the Old World and that control was from the Roman Catholic church. Where the landlord had been able to interpose himself between the church and its disciple, in varying degrees, in Scotland, especially when the persecuted Catholic church needed the protection of the powerful, in the New World this balance was absent. It has been argued that as lay Catholic Gaelic leadership moved inevitably into the English-speaking milieu, the vacuum was filled by the clergy and they were kind to culture.

On the other hand, a fair case may be made that indeed the Roman church was implicated in the extinguishing of some of the old shared joys of the Gaelic classes, when the opportunity came to exert pressure. The temperance movement, particularly in the second half of the 19th century, was culturally proscriptive. All indications are that, after the immigrant generation of Gaels (and intemperance) had died away, the nativeborn Gael was relatively unprotected and subject to certain counter-cultural clerical directives. The disappearances or near disappearances in the last quarter of the 19th century include the old "Wild" Eight-hand reel and the old dancing school. J. L. MacDougall, the Catholic lawyer, was guarded in his anger at the loss of the dancing schools which suggests Roman Catholic 


\section{Scottish Tradition $\mathfrak{Y o l . 2 2} 1997$}

responsibility or connivance. Within living memory the old Four-hand reel has disappeared as a spontaneous céilidh dance. Certainly earlier on, in the immigrant generations when a good dram was seldom turned down, there are examples of Catholic clerical participation in music and dance, notably Fr Allan MacLean (1804-1877) in Judique. MacLean, an Arisaig (Sc) man, was a piper and dancer as well as a bàrd.22

But to every generalisation an exception, and this one entails an example of clerical patronage of piping by a priest in Mabou from the 1890s. The priest, Dr John MacMaster, bought a set of bagpipes for Aonghus Dubh MacDonald (1849-1939) and maintained a lifelong warm social contact with his older parishioner. MacMaster, who was a severe enemy of intemperance, used to take the piper a bottle from time to time; he also made sure the old man had his winter wood supply when he grew weak. In terms of ancestry, Black Angus was of the Killiechonate branch of the Keppochs and more prominent by way of ancestry than Dr MacMaster. However casual their relationship, it was one of sophistication.

In the Presbyterian communities also, there are signs that the old Gaelic shared social consciousness survived the Disruption of 1843 and only weakened when the immigrant generations died away. The big Bachelor MacKinnon who lived at or near Cobb Brook on East Lake Ainslie side dictated for himself a traditional Highland funeral which involved pre-determined stops for generous drinks. Having lived well into Free 


\section{Scottigh Tradition $\mathcal{Y o l . 2 2 ~} 1997$}

Church and temperance times his last wishes were unpopular with the minister. Old residents of the area reported that this was the last funeral of that sort at East Lake Ainslie. However the MacKinnon family included pipers until well within living memory.

In summary, Gaelic language and culture survived the 19th century in Nova Scotia but with noticeable signs of cultural change coming in the last quarter. Traditional bagpiping also made it to well within living memory and is not yet quite extinct. The fundamental strength underlying the survival of traditional piping in Nova Scotia owes much to imperial neglect, out-of-thewayness, the persistence of the ear-learning method used by traditional pipers for centuries, the near absence throughout the century of contact with the imperial military machine, the near absence of competition in piping in Nova Scotia, and to the natural conservativeness of transplanted communities. But added to that is the confidence traditional musicians took from acceptance of their music, in essence traditional stepdance music, by the middle-class Gael. The foundation of that support began to erode after the immigrant generations died and decay has continued fast as unilingual English-speaking Everyman emerges, not into the old Victorian English-speaking world of subtle and unsubtle class distinction but into an Englishspeaking world enfilladed and dominated by postrevolutionary American ideas in which the notion of class is another matter. 
Scottigh Tradition 2001.221997

John G. Gibson 


\section{Scottish Tradition YOol.22 1997}

\section{Endnotes}

1. Ramsay of Ochtertyre remarked upon this. See, Allardyce (ed.), Scotland and Scotsmen in the 18th century. (The published MSS of John Ramsay of Ochtertyre).

2. The Tenures Abolition Act, 1746 (An Act for taking away the tenure of Ward Holding in Scotland, and for converting the same into Blanch and Feu Holdings...20 Geo. 2, c. 50).

3. Heritable Jurisdictions (Scotland) Act, 1746.

4. Chiefly fidelity to these ideals, curtailed by the Statutes of Iona (1609), dropped off at varying times, the last after the failure of the second Jacobite rising (1746) and the gradual enforcement of the anti-Jacobite acts.

5. Unilingualness in the general Gaelic population was profoundly counteracted by the Scottish Education Act of 1872 which deliberately aimed to stamp out Gaelic.

6. Smith juxtaposed the Gaelic tradition and the improver societies in Skye. In the former 'McIan' was content to have a warm and understanding relationship with his tenants while the latter was for cash on the barrel-head and preparing to evict. (See, Smith, A Summer in Skye, 1866.)

7. See, Rae, A School in South Uist.

8. In Keppoch a Mac a'Ghlasraich Campbell and in Beauly near Inverness a MacLean were evicted.

9. Donald MacCrimmon had been MacLeod's piper in the early 1770 s. Until the American revolutionary war he was an illiterate but raised enough men (on his estates) to earn a lieutenant's commission.

10. John MacKay was the last "hereditary" to the Gairloch MacKenzies. He emigrated in 1805 . He was literate and bilingual, Gaelic/English.

11. John Campbell was described as post-carrier and registrar at Invermoriston.

12. See, Piping Times, June 1968. Note also that the Gaelic world contained a number of chiefs, like Glengarry, who 


\section{Scottish Tradition YOol.22 1997}

kept pipers but whose motives for Highlandism were based on nostalgia.

13. Glendessary was a Cameron holding on the marches of South Morar. It was cleared in the early 19 th century.

14. Iain Og Ile's instructions to his collectors emphasize the underground nature of the tradition in the 1860 s very clearly.

15. It was the imminent death of the classical form which MacDonald anticipated which prompted him to dwell on that branch of the subject in his Complete Theory.

16. The cruel irony is that both men were Highlanders.

17. A modern example is the Roman Catholic clergy's promotion of Gaelic song, instrumental music and dance.

18. See, MacDonell Dawson, The Catholics in Scotland. 1890, 520. NB Several relatives of Highland chiefs emigrated. These include: Archibald Campbell, of the Scalpay Campbell family, emigrated in 1830 to Cape Breton; he was married to Matilda MacLeod, grand-daughter of Norman MacLeod, twenty-second chief of the clan MacLeod, and first cousin of Maj-Gen. Norman MacLeod, twenty-third chief, the man whom Lt Donald Maccrumen greeted with "Failte Ruairidh Mhoir" in 1799, (in the presence of a young Norman MacLeod, later author Caraid nan Gàidheal). See, Mackinnon and Morrison, The MacLeods - the Genealogy of a Clan. Section one, "MacLeod chiefs of Harris and Dunvegan."

In the early years of the nineteenth century, Lord MacDonald (Sleat) sent out Alasdair MacDonald, MD (b. 1782 ) to PEI with a ship-load of cleared people. Alasdair the doctor (Alasdair mac Ghilleasbuig 'ic Iain 'ic Dhomhnuil) was the patrilineal great-grandson of the 11 th baron and 4 th Bt of Sleat who had fought at Killiecrankie (1689) and Sheriffmuir (1715). His pedigree and social standing were undeniable. His life in the new world was spent for the most part in Antigonish county, Nova Scotia. 


\section{Scottish Tradition YOol.22 1997}

Likewise, people close to the Keppoch MacDonells and the Coll MacLeans settled in Nova Scotia.

19. Other prominent pipers to come out in the early 19th century were: Iain mac Aindrea Bhàin Mac Gillebhràth (John son of Fair Andrew MacGillivray) (c 1792-1862), an Arisaig man who had been piper to Alexander MacDonald (Alasdair Ruadh) of Glenaladale's in the early nineteenth century. He is remembered a little better than John MacKay but only as a bàrd, a maker of songs. Kenneth Chisholm, the last piper to Chisholm, has left no definite piping traces in Pomquet Forks (Heatherton). This may simply mean that locally-made Gaelic songs praising or including mention of these pipers have been lost with the shift from Gaelic to English, but one thing is certain and that is the adulation given to the "hereditary" great piping families by people like James Logan (1831), Angus Mackay (1838), Kilberry and countless repeaters of the line, is absent from Nova Scotia, and the New World.

20. See, MacDougall's History of Inverness County, MacDonald's Mabou Pioneers and Sagairt Arasaig's "Local History/Genealogy" in MacLean's History of Antigonish County.

21. Conduiligh Rankin was the last of the "hereditary" pipers in MacLean country. He too considered himself of the Gaelic middle class and his biography proves it so.

22. See, The Clansman, Aug./Sept. 1994, citing MacTalla, 5, 13 Mar. 1897.

\section{Bibliography}

Allardyce, Alexander (ed), Scotland and Scotsmen in the 18th century, 1888.

Campbell, J.F., Popular Tales of the West Highlands, Orally Collected with a Translation, 4 vols, Edinburgh, 1860 and 1862. 


\section{Scottish Tradition YOol.22 1997}

Cheape, Hugh, "Highland and Jacobite Culture," in "The Swords and the Sorrows, Claidheamhan is Bròn,' n.d., c 1995.

Clerk, Rev. A, LL.D., (minister of Kilmallie) (ed), Caraid nan Gàidheal (The Friend of the Gael.) A choice selection of the Gaelic Writings of the late Norman MacLeod, D.D., of St. Columba Parish, Glasgow ... with a memoir of the author by his son, the late Norman MacLeod, D.D., of the

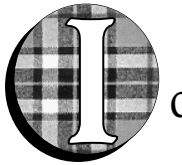
Barony Parish, Glasgow. New Edition, Edinburgh, 1899.

Cromb, David L., (edited and brought down to the end of the Boer War, 1902), The Highland Brigade: its Battles and its Heroes, Stirling, 1902.

Fleming, James A., The Scots Statutes Revised, The Public General Statutes affecting Scotland, 1707-1819, Edinburgh, William Green \& Son, Law Publishers, 1899.

Johnston, Rev. A.A., A History of the Catholic church in Eastern Nova Scotia, 2 vols, Antigonish, 1960 and 1971.

Logan, James, The Scottish Gael; or, Celtic Manners, as preserved among the Highlanders: 2 vols, London, 1831.

MacDonald, Alexander D. (1907-1956), The Mabou Pioneers, re-issue, n.d. (author d 1956).

MacDonald, Joseph, "Compleat theory of the Scots Highland Bagpipe with all the Terms of Art in which this instrument was originally taught by its first masters $\&$ composers in the islands of Skye \& Mull," Laing MS, Edinburgh University Library, c 1761.

MacDougall, J.L., History of Inverness County, 1922 and 1976 (reprint).

MacKay, Angus, A Collection of Ancient Piobaireachd or Highland Pipe Music, many of the pieces being adapted to the piano forte with full instructions for those desirous of qualifying themselves in performing on the National Instrument, to which are prefixed some sketches of the principal Hereditary Pipers and their Establishments with historical and traditional notes respecting the origin of the various pieces. Dedicated by permission to the Highland 


\section{Scottish Tradition $\mathfrak{Y o l . 2 2} 1997$}

Society of London, Wakefield, 1972.

MacKay, Squire John J.P., "Reminiscences of a Long Life", published by the Oban Times in the 1930s, MS held by the PANS, (Public Archives of Nova Scotia), MG20 6747.

MacKinnon and Morrison, The MacLeods - the genealogy of a clan, Section one, "MacLeod chiefs of Harris and Dunvegan."

MacLean, R.A., (ed), History of Antigonish, Antigonish, Nova Scotia.

MacLean, R.A., The Casket 1852-1992 From Gutenberg to Internet: The Story of a Small-Town Weekly, Casket Printing \& Publishing Company Ltd., Antigonish, Nova Scotia, 1995.

McDonell Dawson, Aeneas, The Catholics of Scotland From 1593, and the Extinction of the Hierarchy in 1603, till the Death of Bishop Carruthers in 1852, London, Ontario, 1890.

Rae, F.G., A School in South Uist, (edited by J.L. Campbell), London, 1964.

Smith, Alexander, A Summer in Skye, 1866.

Stewart, Colonel David of Garth, Sketches of the Character, Manners, and Present State of the Highlanders of Scotland: with Details of the Military Service of the Highland Regiments, 2 vols, Edinburgh, 1822.

The Clansman, Aug./Sept. 1994.

Turreff, Gavin, Antiquarian Gleanings from Aberdeenshire Records, 2nd edition, Aberdeen, 1871. 